\title{
Social Capital Generation Inside Science Parks: An Analysis Of Business-University Relationships
}

Ricardo Martínez-Cañas, University of Castilla-La Mancha, Spain Pablo Ruiz-Palomino, University of Castilla-La Mancha, Spain

\begin{abstract}
The importance of inter-organizational relations for business competitiveness is widely known. In recent years numerous researchers have been studying firm's relationships using social capital theoretical framework as a multidimensional concept that integrates various facets of relationships. The empirical evidence in the literature show that is a valuable corporate asset that can determine firm performance. Focusing on Science Parks as a facilitating landscape promoting interactions with Universities and Research Centres, we conducted an empirical analysis on a sample of technological companies located inside Spanish Science Parks. In our research we found that firms' relations with universities generate social capital and once created it had a significantly positive effect on firm performance measured as knowledge acquisition and reputation of firms. Contrary to our expectations generated social capital has no significant effect on the development of new products and in the technological distinctiveness of firms.
\end{abstract}

Keywords: Social Capital, Science Parks, Innovation, Inter-Organizational Relationships, Innovation

\section{INTRODUCTION}

$\mathrm{n}$ recent years, research in social capital has provided a distinctive and valuable answer to the question of why some people and some organizations do better in the sphere of inter-organizational relations (Nahapiet, 2008). This fact can help researchers to explain why and how organizations connect effectively, work cooperatively and coordinate their activities to achieve a superior performance in the market. From this theoretical perspective, oriented toward strategic relatedness, firms are motivated to generate, develop and maintain relationships with others organization because relations ease the access to key resources, information, markets, technologies, advantages from knowledge and learning, scale and scope economies, as well as risk sharing (Gulati, Nohria \& Zaheer, 2000).

To study social capital we try to converge two related lines of research: Science Parks and organizational social capital. On the one hand, we analyse Science Parks as an artificial physical structure that facilitate interaction among the economic agents located inside (Hansson, 2007). But from the point of view that the main value of Science parks are the interactions among firms, universities and the management staff of the park that help firms to face changes in their environment. So, we focus on Science Parks using the view of networks and knowledge-based organizations as the main source of competitive advantage in the market (Nahapiet, 2008).

On the other hand, we are considering that our unit of analysis are interorganizational relationships between agents. So, we propose an approximation of study from the relational view (Dyer and Singh, 1998) and from the theory of social capital (Westlund, 2006). This relational approach considers all interactions between economic agents generate a type of capital that in the literature is known as social capital. Thus, we contribute to previous work considering that economic agents interact in environments that influence and affect their business (Burt, 2005). In our study, the positive environment created by Science Parks facilitates access to valuable resources. Those specific valuable resources that firms need to survive, grow and compete (Powell, Kogut and Smith-Doerr, 1996) are 
located in Science Parks environment, and extends the effect of resources available to the organization (Adler and Kwon, 2002; Westlund, 2006). The paper proceeds as follows. We first explain the theoretical framework using social capital theory in the context of Science Parks and then we proposed hypothesis. A description of the research method and main results found in this study is provided next. Finally, a summary is presented in which we outline possible limitations, contributions and implications for future research.

\section{THEORETICAL BACKGROUND AND HYPOTHESES}

Science Parks create a physical landscape that enables economic agent's interaction within the same geographical area (Hansson, 2007). We consider that the relations between firms and Universities can generate valuable organizational social capital. The term social capital has become a popular way of denoting many kinds of resources appropriable from relationships (Nahapiet and Ghoshal, 1998). It is relatively easy to describe social capital as the wealth or benefit that exists because of an agent's social relationships (Lesser 2000). To study the wealth generated in relationships we use the conceptual model of social capital proposed by Adler \& Kwon (2002). This model is structured into four main parts: 1) the generation of social capital, 2) the main dimensions (structural, cognitive and relational), 3) the positive effect on business performance and 4) the contingent value of the social capital.

In the first part of our model we identify that organizational social capital is generated in relationships of tenant firms with Universities. Adler and Kwon (2002) consider that the key sources of social capital are networks, norms, social beliefs and rules. They consider that each of these sources makes a distinct contribution to the formation of social capital although all three are mutually interdependent. So, the primary sources can be considered as direct sources generated with the important role of formal institutions (or more specifically rules) and trust as indirect sources or even direct sources of social capital. In the second part of the model, they identify the three main dimensions of social capital: Structural, Relational and Cognitive. These dimensions are the effect or "more or less durable social relations" that influence the development of the mutual benefits of social capital (Lesser, 2000): the structure of the relations, the interpersonal dynamics that exist within the structure and the common context and language held by individuals in the structure. In the first dimension we consider, social capital from an egocentric perspective in relations because we are concerned with the connections that firms have with Universities. With the second, the relational dimension, we consider that social capital is not limited to the presence of contacts within the given network, and the positive interactions between individuals in the network lead also to the formation of social capital. In the literature, this facet of the relationship has been already discussed with concepts as trust and reciprocity (Nahapiet, 2008). As, the third enabler of social capital we identify the "common language" that individuals can use. This use of "common language" includes but goes beyond languages, and addresses also the acronyms, subtleties and underlying assumptions that are the necessities of everyday communication (Lesser, 2000). Trying to follow the structure of the theoretical model proposed by Adler and Kwon (2002) we are going to consider social capital as only one construct formed by his three main dimensions.

In the third part we analyze that organizational social capital can make collective action more efficient, because it becomes a substitute for the formal contracts and mechanisms of the market (Lesser, 2000). Trust, relationships and shared norms offer a possibility for individuals in organizations to work more effectively as a collective. From that point of view, social capital can provide a favourable environment to knowledge creation and combination can facilitate the development of intellectual capital within a firm (Nahapiet and Ghoshal, 1998). Organizational social capital provides network ties and connections that can be used more efficiently for information and knowledge sharing than formal mechanisms. Shared understanding of norms, habits and even language can also help knowledge to flow more freely and efficient in a firm and therefore the intellectual capacity of the firm increases (Westlund, 2006). In the last part the model incorporates the interactive and moderating effect due to both firm's capabilities and task contingencies, but this part of the model is not included in our study. In University-Firms relationships we consider that social capital contributes to some firm benefits by improving access to external sources that helps firm to get a higher development of new products and services, a better technological distinctiveness, an improved efficiency of knowledge acquisition and an enhanced reputation. 
New products development: The value of social capital as an enabler depends on the willingness of exchange partners to engage in two-way interaction. The knowledge that firms can derive from their relationships may be particularly valuable for the development of new products and services (von Hippel, 1988). As a consequence, tenant firms can use laboratories, infrastructures and services that University are offering inside Science Parks. For Universities, firms can represent a source of timely, accurate, tacit, and confidential information on e.g. developments in related technologies and customer needs. A high level of information exchange with a firm may thus enhance the ability of the firm to develop new products and bring them to the market. Also, as literature suggests, social capital enables innovation (Zheng, 2010). We can express this idea formally as follows:

Hypothesis 1: The higher the level of social capital in University-firm relationships, the more will be the number of new products and services developed by the firm.

Technological distinctiveness: Several studies provide empirical evidence implicitly linking learning with knowledge distinctiveness in new ventures. Value is enhanced by distinctiveness: the more distinctive the resource, the more readily it can be leveraged for rent-generating purposes. Because tenant firms located in Science Parks do not possess sufficient resources to compete with volume and cost-efficiency, distinctiveness is the primary mechanism for achieving competitive advantage, particularly in high-technology sectors. We can summarize that social capital enhances technological distinctiveness (Yli-Renko et al, 2001) and we hypothesize:

Hypothesis 2: The higher the level of social capital in University-firm relationships, the more distinctive will be the technology of the firm.

Knowledge acquisition: Learning increases the distinctiveness of the firm's knowledge base, as new intellectual capital is created by innovatively combining firm-specific knowledge with Universities knowledge and resources. According to the resource-based theory, four basic conditions enhance the rent-generating potential of resources: scarcity, non-substitutability, imperfect imitability, and resource value (Barney, 1991). As literature supports, social capital facilitate knowledge acquisition of value-resources key for competitive advantage (Yli-Renko et al., 2001). In line with the above arguments we can postulate that:

Hypothesis 3: The higher the level of social capital in University-firm relationships, the more distinctive will be the knowledge acquisition of the firm.

Firm reputation: In social capital literature some researchers support the idea that social capital generate a better firm's reputation (Yli-Renko et al, 1999; Wiedmann and Hennings, 2006). Their assumptions are that the more information a customer has about a tenant firm located in a Science Park, the more authoritatively it will be able to detail to other potential customers the benefits and strengths of dealing with the firm, thus improving the reputation of this firm. So we can suggest that:

Hypothesis 4: The higher the level of social capital in University-firm relationships, the more reputation will have the firm.

\section{METHODOLOGY AND RESULTS}

\section{Sample}

For testing the three main parts of the model proposed by Adler and Kwon (2002) we sent a survey of CEO's from a sample of 1280 Spanish firms from 21 Science Parks. Those firms were from sectors such as aerospace and automotive, training and human resources, information technology, medicine, biotechnology, engineering, consultancy and environmental activities. We used the more comprehensive database of firms located that is available in the Spanish Association of Science Parks (APTE) to identify tenant firms for the above industries and with a high add-value in their activities. We received 214 valid questionnaires (16.87 of response rate) and we processed the data with a Structural Equation Model using the technique of Partial Least Squares (Chin, 1998). 


\section{Items/Constructs measures}

For measuring latent constructs we used items previously accepted in the literature for dimensions of social capital (Nahapiet and Ghoshal, 2008; Yli-Renko et al, 2001; Chakrabarti and Santoro, 2004), new products development (von Hippel, 1998), technological distinctiveness (Wernerfelt, 1984; Yli-Renko et al, 2001), knowledge acquisition (Ye, 2005) and firm's reputation (Wiedmann and Hennings, 2006).

\section{Assessment of the measured model (first and second order)}

With regard to the measurement model, all were reflective latent constructs (Chin, 1998). As recommended by Chin (2010) we assessed: individual item reliability, construct reliability, convergent validity and discriminant validity of all the items from first and second order constructs. For the individual item reliability we considered adequate when the value of its standardized load equals to or is over 0.707 (Carmines and Zeller, 1979). For construct reliability, we evaluated it by examining their composite reliability of the constructs (Werts, Linn and Joreskog, 1974). For Convergent validity we evaluated by means of the Average Variance Extracted (AVE) which should be greater than 0.5 (Fornell \& Larcker, 1981). Finally, for discriminant validity, according to Barclay et al. (1995) all reflective indicators should load more highly on their own construct than on others. In addition, AVE should exceed the variance shared between the reflective construct and other constructs in the model (Fornell \& Larcker, 1981). As is showed in Table 1, both indicators and latent variables exceed the conditions above proposed for assess the four conditions that determines a good measured model.

Table 1. Assessment of the measured model

\begin{tabular}{|c|c|c|c|c|}
\hline \multicolumn{5}{|c|}{ First Order Constructs } \\
\hline Constructs (items) & $\begin{array}{c}\text { Individual Items } \\
\text { Loadings } \\
(>0.55 \sim 0.707)\end{array}$ & $\begin{array}{c}\text { Composite } \\
\text { Reliability }(>0.7)\end{array}$ & $\begin{array}{c}\text { Convergent } \\
\text { Validity } \\
(\mathbf{A V E}>\mathbf{0 . 5 0})\end{array}$ & $\begin{array}{c}\text { Discriminant } \\
\text { Validity }\end{array}$ \\
\hline Structural dimension $\{9\}$ & From 0.63 to 0.87 & Yes $(0.931)$ & Yes (0.549) & Yes \\
\hline Cognitive dimension $\{7\}$ & From 0.71 to 0.83 & Yes $(0.920)$ & Yes (0.604) & Yes \\
\hline Relational dimension $\{4\}$ & From 0.71 to 0.87 & Yes $(0.875)$ & Yes $(0.579)$ & Yes \\
\hline $\begin{array}{l}\text { Technological } \\
\text { Distinctiveness }\{4\}\end{array}$ & From 0.79 to 0.88 & Yes $(0.911)$ & Yes (0.700) & Yes \\
\hline Knowledge Acquisition $\{4\}$ & From 0.74 to 0.85 & Yes $(0.893)$ & Yes $(0.690)$ & Yes \\
\hline Reputation $\{2\}$ & From 0.90 to 0.93 & Yes (0.919) & Yes $(0.850)$ & Yes \\
\hline \multicolumn{5}{|c|}{ Second Order Constructs } \\
\hline $\begin{array}{l}\text { Social capital in } \\
\text { University-firms } \\
\text { relationships }\end{array}$ & From 0.91 to 0.97 & Yes $(0.965)$ & Yes $(0.811)$ & Yes \\
\hline
\end{tabular}

\section{Structural model: hypothesis testing}

In figure 1, and on the basis of this empirical data, the proposed model is partially supported. On the left side of the model, first order constructs (structural, cognitive an relational dimensions) are significant and reflect the second order latent construct (social capital). On the right side of the model we have found a positive and significant association in support of Hypothesis $\mathrm{H}_{3}(\beta=.292 ; \mathrm{p}<.001)$ and $\mathrm{H}_{4}(\beta=.148 ; \mathrm{p}<.05)$. So, the positive relationship predicted between the social capital and knowledge acquisition and firm's reputation was confirmed. Contrary to our expectations we have found a positive but not significant association in support of Hypothesis $\mathrm{H}_{1}$ and $\mathrm{H}_{2}$ (new products development and technological distinctiveness). Analyzing the $R^{2}$ values of the endogenous constructs, it can be stated that our research model has a weak predictive power, because only firm's reputation construct is explained in a percentage higher than $10 \%$ which is the optimal minimum according to Falk and Miller (1992). 


\section{DISCUSSION}

We can conclude that the main results obtained in this paper are that social capital is generated in relations with Universities. Also, we found that social capital has positive and significant facets (structural, cognitive and relational) reflected in each dimension. Furthermore, social capital generated through relationships with Universities had positive and significant effect on knowledge acquisition and reputation. Contrary to what we have hypothesised social capital had no significant positive effect on the development of new products and technological distinctiveness. We think that we need to include in further studies more constructs and variables to explain these variables. We believe this research has positive implications for both park managers and for tenant firms. Park managers should adopt proactive strategies that facilitate the promotion of relations between Universities and firms for obtaining better results due to the interaction. These activities complement their formal activities for advising, space management and creating high value services. And for firms located, the results of our investigation show that firms should be proactive with relationships they establish with Universities because contribute greatly to improving their performance. To finalize we conclude with some limitations of this research like that it's difficult to extrapolate the results in other sectors-countries, that our study can have biases related to asking dependent and independent variables in questionnaires and that we are only measuring social capital in one moment of time. As future lines of research we should include more independent variables and we should analyze relations with other agents (inside and outside the park).

Figure 1. Social capital in university-firm relationships*

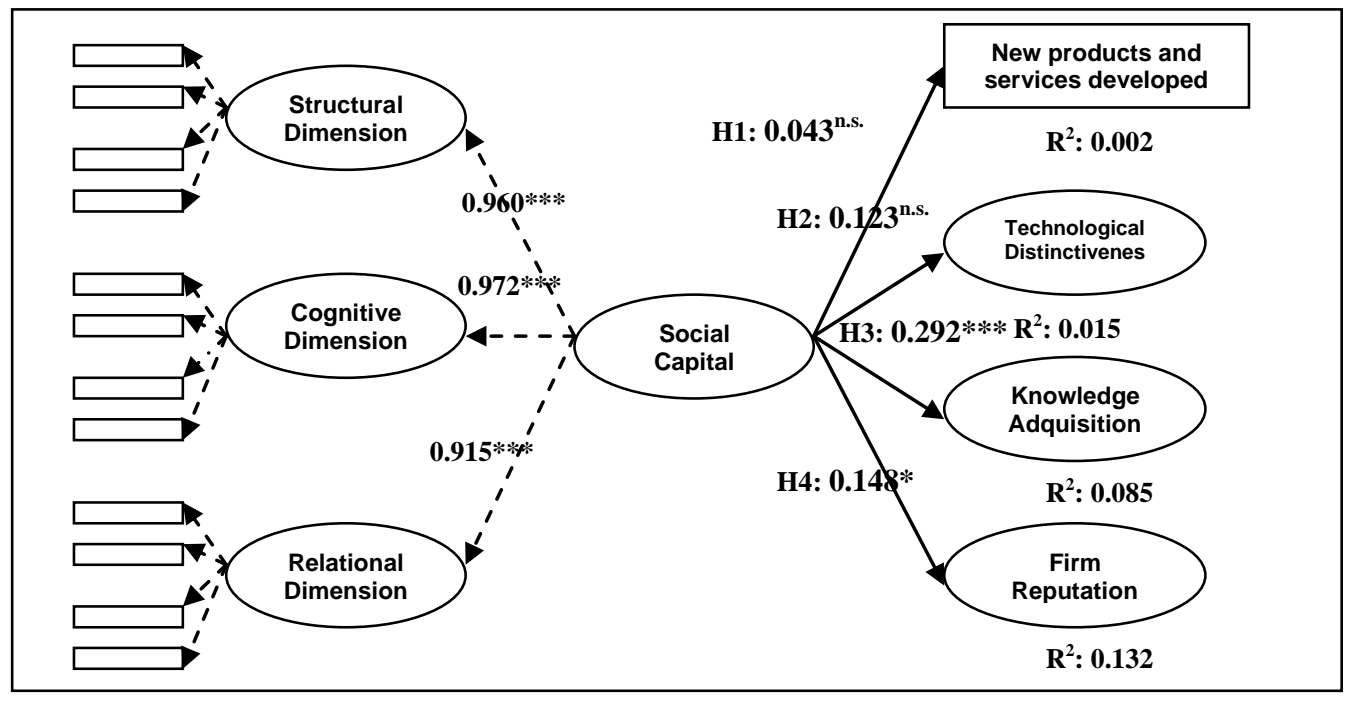

\section{AUTHOR INFORMATION}

Ricardo Martínez-Cañas: PhD in Business Management by University of Castilla-La Mancha. Assistant Professor at Business Management Department. Faculty of Social Sciences of Cuenca. University of Castilla-La Mancha (Spain). E-mail: Ricardo.Martinez@uclm.es.

Research Interest: organizational social capital, science parks, business ethics and leadership.

Pablo Ruiz-Palomino:PhD in Business Administration and Degree in Business Administration by University of Castilla-La Mancha. Assistant Professor at Business Management. Faculty of Social Sciences of Cuenca. University of Castilla-La Mancha (Spain). E-mail: Pablo.Ruiz@uclm.es.

Research Interest: business ethics and social capital. ${ }^{*}$ Notes: $* * * \mathrm{p}<.001, * * \mathrm{p}<.01, *{ }^{*}<.05,{ }^{+} \mathrm{p}<.1$ (based on a Student $\mathrm{t}{ }_{(499)}$ two-tailed test): $\mathrm{t}(0.001 ; 499)=3.310124157 ; \mathrm{t}$
$(0.01 ; 499)=\mathbf{2 . 5 8 5 7 1 1 6 2 7 ;} \mathrm{t}_{(0.05 ; 499)}=\mathbf{1 . 9 6 4 7 2 6 8 3 5} \mathrm{y} \mathrm{t}_{(0.1 ; 499)}=\mathbf{1 . 6 4 7 9 1 3 4 5}$ 


\section{REFERENCES}

1. Adler, P. \& Kwon, S.W. (2002): "Social Capital: Prospects for A New Concept", Academy Of Management Review, 27, 17-40.

2. Barclay, D., Higgins, C. \& Thompson, R. (1995). The Partial Least Squares (PLS) Approach to Causal Modelling: Personal Computer Adoption and Use as an Illustration, Technology Studies, Special Issue on Research Methodology, 2 (2), 285-309.

3. Barney, J. B. (1991): "Firm Resources and Sustained Competitive Advantage", Journal of Management, 17(1), 9-120.

4. $\quad$ Burt, R.S. (2005). Brokerage and Closure: An Introduction to Social Capital. Oxford University Press

5. $\quad$ Carmines, E.G. \& Zeller, R.A. (1979). Reliability and Validity Assessment. Sage University Paper Series on Quantitative Applications in the Social Sciences (7-17). Beverly Hills: Sage Publications.

6. $\quad$ Chakrabarti, A.K \& Santoro, M.D. (2004):”Building Social Capital and Learning Environment In University - Industry Relationships", International Journal Of Learning And Intellectual Capital, 1 (1), 1935

7. Chin, W. (2010). How To Write Up And Report PLS Analyses. In: V. Esposito Vinzi, W. Chin, J. Hensler, and H. Wold (Eds.,) Handbook of Partial Least Squares, (655-690). Heidelberg: Springer.

8. Chin, W. (1998). The Partial Least Squares Approach To Structural Equation Modelling. In G.A. Marcoulides (Ed.), Modern Methods For Business Research (295-336). New York: Lawrence Erlbaum Associates.

9. Dyer, J.H. \& Singh, H. (1998): “The Relational View: Cooperative Strategy and Resources of Interorganizational Competitive Advantage", Academy Of Management Review, 23 (4), 660-679.

10. Falk, R.F. \& Miller, N.B. (1992). A Primer For Soft Modelling, Akron, Oh: The University Of Akron Press.

11. Fornell, C. \& Larcker, D.F. (1981). Evaluating Structural Equation Models with Unobservable Variables and Measurement Error. Journal of Marketing Research, 18 (1), 39-50.

12. Gulati, R., Nohria, N. \& Zaheer, A. (2000): "Strategic Networks", Strategic Management Journal, 21(3), 203-215.

13. Hansson, F. (2007): "Science Parks as Knowledge Organizations: The "Ba" In Action?" European Journal of Innovation Management, 10 (3), 348-366.

14. Lesser, E. L. (2000): "Leveraging Social Capital In Organizations"; En Lesser E. L. (Ed.): Knowledge And Social Capital: Foundations And Applications, Butterworth-Heinemann, 3-16.

15. Nahapiet, J. (2008). Social Capital and Interorganizational Relations. In S. Cropper, M. Ebers, C. Huxham and P. S. Ring (Eds.) The Oxford Handbook of Interorganizational Relations. Oxford: Oxford University Press. 580-606.

16. Nahapiet, J. \& Ghoshal, S. (1998): "Social Capital, Intellectual Capital and the Organizational Advantage", Academy Of Management Review, 23, 242-266.

17. Powell, W.W., Koput, K.W. \& Smith-Doerr, L. (1996): "Interorganizational Collaboration and the Locus of Innovation: Networks of Learning in Biotechnology", Administrative Science Quarterly, 41(1), 116-145.

18. Werts, C.E., R.L. Linn \& K.G. Joreskog (1974). Interclass Reliability Estimates: Testing Structural Assumptions. Educational and Psychological Measurement, 34 (1), 25-33.

19. Westlund, H. (2006): Social Capital in the Knowledge Economy. Theory and Empirics, Springer, Berlin.

20. Wiedman, K.G. \& Hennings, N. (2006): "Corporate Social Capital And Corporate Reputations", 10th Conference On Reputation, Image, Identity \& Competitiveness, 25-28 May, New York.

21. Ye, F. (2005): "Strategic Partnerships in Transformational Outsourcing as A Distinctive Source of Is Value: A Social Capital Perspective", Unpublished Dissertation, Robert H. Smith School of Business, University of Maryland.

22. Yli-Renko, H., E. Autio \& H. Sapienza (2001): "Social Capital, Knowledge Adquisition and Knowledge Exploitation in Technology-Based New Firms", Strategic Management Journal, 22, 587-613.

23. Zheng, W. (2010). A Social Capital Perspective Of Innovation From Individuals To Nations: Where Is Empirical Literature Directing Us? International Journal of Management Reviews, Vol. 12 (2), 151-183. 